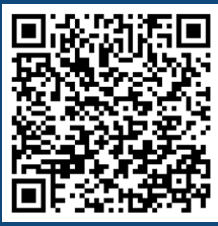

Keywords:

Fine roots

Small root

Coarse root

Macro elements

Micro elements

Historic: Received 03/09/2019 Accepted 07/02/2020

Correspondence: sakburak@istanbul.edu.tr
Serdar Akburak ${ }^{\mathrm{la}+}$

\section{VARIATIONS OF ELEMENT CONCENTRATIONS IN ROOTS OF DIFFERENT TREE SPECIES.}

\author{
AKBURAK, S. VARIATIONS OF ELEMENT CONCENTRATIONS IN ROOTS OF \\ DIFFERENT TREE SPECIES. CERNE, v. 26, n. I, p.I I8-I29, 2020.
}

\section{HIGHLIGHTS}

The concentrations of elements showed significantly difference between species.

Oak had higher element concentrations than coniferous in all root diameters

Fe concentration in coarse roots of oak species showed antagonistic interaction with $\mathrm{Mg}$ and Ca.

Nutrient storage properties of roots had differences between natural and plantations species

\section{ABSTRACT}

Element concentrations of roots play an important role for plant growth and below ground biochemical cycles in forest ecosystems. It can show a change among species. This research aimed to determine changes in the nutrient content for different root diameters of trees in the Belgrad forest. Natural species of Sessile oak (Quercus petraea L.), Scots pine (Pinus sylvestris L.), Austrian pine (Pinus nigra Arnold.), Turkish fir (Abies bornmuelleriana L.), and Oriental spruce (Picea orientalis L.) were studied. Root sampling was carried out by randomly collecting twenty soil samples within each species once every three months (from April 2007) over one year. Roots were classified by fine root $(<2 \mathrm{~mm})$, small root $(2-5 \mathrm{~mm})$ and coarse root $(>5 \mathrm{~mm})$ diameter classes. Total concentration of elements $(\mathrm{K}$, $\mathrm{Ca}, \mathrm{P}, \mathrm{Fe}, \mathrm{Mg}, \mathrm{Cu}, \mathrm{Mn}, \mathrm{Al}, \mathrm{Ni}, \mathrm{Zn}, \mathrm{Na}$ ) in each root classes were determined. The macro elements $\mathrm{Mg}, \mathrm{K}$, and $\mathrm{P}$ and all microelements in the included species showed a tendency to decrease in concentration with increasing root diameters. Macro elements except $\mathrm{K}$ and $\mathrm{P}$ and microelements except $\mathrm{Pb}, \mathrm{Al}, \mathrm{Zn}$, and $\mathrm{Cu}$ showed a significant temporal difference between species based on the root diameters. $\mathrm{Al}, \mathrm{Pb}, \mathrm{Ni}, \mathrm{Mn}$, and Fe showed different antagonistic relations with $\mathrm{Ca}, \mathrm{Mg}, \mathrm{P}$, and $\mathrm{K}$ between species with regard to their concentration in fine roots. There was no significant negative correlation between small and coarse roots in species (except in oak species). The results have shown that nutrient storage characteristics differ between different species in the same site. 


\section{INTRODUCTION}

Because an important part of the whole biomass in the ecosystem forms belowground plant parts, these are important for nutrients and organic substances entry to soil via the roots and for maintaining soil productivity (Lehmann and Zech, 1998). Root structures of tree have a crucial role in ecosystem processes (Bardgett et al., 2014; Brunner et al., 2015; McCormack et al., 2015; Tsunoda and van Dam, 2017).

Roots are generally considered as organs that provide nutrients to plant tissues rather than the main nutrient sink (Aerts and Chapin III, 1999). The contribution of fine roots to the nutrient pool can be equal to and even greater than that of leaf tissues (Hobbie et al., 2010; Pallardy, 2008). In particular, root dynamics play an significant role in the evaluation of net primary production of terrestrial ecosystems (Van der Putten et al., 2013; Yang et al., 2010). The input to soil the with the decomposition of fine roots is important for the health of the forests, continuity of growth, soil microfauna in the root zone, and population of microflora (Bloomfield, 1996).

Roots $(<2 \mathrm{~mm})$ are very sensitive to changes in nutrient cycle and micro-conditions in the soil (e.g temperature, moisture, depth) (Han et al., 2019; Inagaki et al., 2009; Tian, 2002). Therefore, monitoring the amount and temporal changes in fine root dynamics may reflect changes in the ecosystem (Assefa et al., 2018; Chen et al., 2017; Vogt et al., 1993).

The small and coarse roots are multifunctional tree components providing main functions in root structure such as transportation of food, water, and photosynthesis products, storage of sugar and nutrients, and biochemical stability. In addition, they form the skeleton for development of fine root (Fortier et al., 20I5; Guo et al., 2013). Coarse roots have slow decomposition ratios and can contribute to the belowground nutrient budget for long-term (Fortier et al., 2015; Liski et al., 2014). Therefore, determination of element stocks in small and coarse roots is important for understanding the belowground element cycle in forest ecosystems.

The nutrient concentration in the roots may vary depending on the annual growth ratio and the intake of nutrients (Helmisaari, 1991). The nutrients stocks in fine roots supplies important knowledge about the nutritional conditions of trees (Persson and Ahlström, 2002). Many studies on this topic are available in the literature (Gordon and Jackson, 2000; Hellsten et al., 20I3; livonen et al., 2006; Yuan and Chen, 20I0). However, even though there are studies on root biomass in forest ecosystems, studies on how elemental content in different root diameters varies between species are quite inadequate. In our study, one deciduous species, Quercus petraea L., and coniferous species such as, Pinus sylvestris L., Pinus nigra Arnold., Abies bornmuelleriana L. and Picea orientalis L. were chosen. Quercus petraea L., Pinus sylvestris L., Pinus nigra Arnold. have vast distribution in European and Turkey, although, Abies bornmuelleriana L. and Picea orientalis L. have local distributions in Turkey. The objective and scope of this study is to determine changes in the nutrient content of different diameters of tree roots in selected species at the same site.

\section{MATERIAL AND METHODS}

\section{Research area}

The research area is located at Istanbul Belgrad Forest, Turkey. The long-term, avarage annual temperature and precipitation were approximately $13^{\circ} \mathrm{C}$ and $1,074 \mathrm{~mm}$, respectively. The area are characterized by Mediterranean climate (Akburak and Makineci, 2013). The soil of the research area is Luvisol and its texture is loam. The research areas were instituted in 1950 by introducing conifer species adjacent to natural oak species (Akburak et al., 20I3; Sevgi et al., 20I I).

\section{Field data and measurements}

Sampling were carried out in four conifer plantation, Oriental spruce (Picea orientalis L.), Austrian pine (Pinus nigra Arnold), Turkish fir (Abies bornmulleriana L.), Scots pine (Pinus sylvestris L.), and one natural deciduous forest, Sessile oak (Quercus petraea L.), as common garden experiments without replications (Akburak and Makineci, 20I3; Akburak et al., 20I3).

The soil was comparatively undisturbed because any forest treatments were not applied after the establishment. Tree stand characteristics is shown in Table I (Akburak et al., 20I3).

Root core sampling was carried out by randomly collecting twenty soil samples (5 sampling points $\times 4$ repetitions $=20$ soil cores) within each species once every three months (from April 2007) over one year (Akburak et al., 20I3). Thus, 400 soil cores in total (5 tree TABLE I Characteristics of trees on sample plots.

\begin{tabular}{cccccc}
\hline Characteristics & Sessile Oak & $\begin{array}{c}\text { Turkish } \\
\text { Fir }\end{array}$ & Oriental Austrian & Scots \\
\hline $\begin{array}{c}\text { Tree number } \\
\left(\mathrm{ha}^{-1}\right)\end{array}$ & 444 & 1,206 & $\mathrm{I}, 54 \mathrm{I}$ & $\mathrm{I}, 206$ & $\mathrm{I}, 005$ \\
\hline $\begin{array}{c}\text { Diameter }(\mathrm{dbh}) \\
(\mathrm{cm})\end{array}$ & 26.6 & 16.8 & 19.7 & 27.3 & 27.2 \\
\hline $\begin{array}{c}\text { Height } \\
(\mathrm{m})\end{array}$ & 20 & 17.1 & 16.4 & 16.7 & 18.0 \\
\hline
\end{tabular}


species $\times 20$ soil cores $\times 4$ sampling times $=400$ ) were collected in the study. Samples were taken from $35 \mathrm{~cm}$ deep with cylindrical soil core $(\varnothing 6.4 \mathrm{~cm})$ (Tüfekçioğlu and Küçük, 2004).

The root samples were separated from soil by washing and sieving (Tüfekcioğlu and Küçük 2004). Roots were classified by fine root $(<2 \mathrm{~mm})$, small root $(2-5$ $\mathrm{mm}$ ) and coarse root ( $>5 \mathrm{~mm}$ ) diameter classes (Akburak et al., 20I3; Tüfekçioğlu and Küçük, 2004). Dry mass of all roots (at $65^{\circ} \mathrm{C}$ for $24 \mathrm{~h}$ ) were determined (Akburak et al. 2013). Samples were digested with concentrated $4 \mathrm{ml}$ $\mathrm{HNO}_{3}$ (\% 65) and $2 \mathrm{ml} \mathrm{H}_{2} \mathrm{O}_{2}$ (\% 37) in microwave oven (Berghoff Speedwave). The samples were converted into solutions via microwave digestion system. The solutions were then prepared with ultra-pure water until the final volume reached $50 \mathrm{ml}$ and these were stored at $4{ }^{\circ} \mathrm{C}$ until they were analyzed. Total concentration of elements $(\mathrm{K}$, $\mathrm{Ca}, \mathrm{P}, \mathrm{Fe}, \mathrm{Mg}, \mathrm{Cu}, \mathrm{Mn}, \mathrm{Al}, \mathrm{Ni}, \mathrm{Zn}, \mathrm{Na}$ ) in solutions were determined by ICP-OES (Perkin Elmer Optima 7000 DV) spectrometer (Çakır and Akburak, 20I7).

\section{Data analysis}

Statistical tests were done with SPSS 21.0 software. Normality of the data obtained according to the species was tested by the Kolmogorov-Smirnov test. As a result of this test, the data not normally distributed were shown to be normal with Box-Cox transformation. ANOVA used to compare element concentrations in all roots (fine, small and coarse) of tree species. Comparisons among species were determined using the Duncan test. Also, Multivariate MANOVA analysis was applied in order to determine the differences between nutrient elements according to temporal, interspecific and root diameter classes. In addition, the relationships between the elements in the roots were tested with Pearson correlation analysis.

\section{RESULTS}

\section{Variations in macroelements concentrations}

The concentrations of macro elements ( $\mathrm{Ca}$, $\mathrm{K}, \mathrm{Mg}$, and $\mathrm{P}$ ) showed significant differences between both root diameters and species (Table 2). Except Ca concentration in oak, and spruce, all macro element concentrations showed a tendency to decrease as the root diameter increases (Table 3). In terms of $\mathrm{Ca}$ concentration in fine roots, Austrain pine significantly lower from other species. However, Ca concentration in small and coarse roots of oak was statistically higher than that in other coniferous. The level of $\mathrm{K}$ and $\mathrm{Mg}$ in fine and small roots of oak species differed statistically from other species, and concentration of $\mathrm{K}$ in the coarse roots of spruce species was significantly different from other species. In terms of $\mathrm{P}$ concentration in fine roots, oak species showed a similar tendency to other species. $P$ concentration in the coarse roots of spruce differed statistically from that in the roots of other species.

The concentration of $\mathrm{Ca}$ and $\mathrm{Mg}$ were significantly different between species according to their root diameter temporarily (Table 2). Ca content generally showed significantly decrease in the fine roots in the oak and fir species in July, whereas there was significantly increase in $\mathrm{Ca}$ concentration in other species (except to Austrian pine) (Figure I). In general, Ca concentration in small roots showed significantly increase in oak and spruce species, whereas that in other species showed a decrease in July (Figure 2). The $\mathrm{Ca}$ concentrations in the coarse roots of oak and fir generally showed a tendency to decrease during the study period (Figure 3).

$\mathrm{Mg}$ concentration in the fine roots showed significantly decrease only in oak species in July, but there was significantly increase in $\mathrm{Mg}$ concentration in other species (Figure I). Regarding Mg concentration in small roots, oak and Austrian pine species showed significantly increase in July (Figure 2). Only spruce species showed significantly increase in $\mathrm{Mg}$ concentration in coarse roots in July. The concentration showed a tendency to decrease in Austrian pine and fir species during the study period (Figure 3).

When the $\mathrm{K}$ concentrations were examined, concentrations in fine and small roots decreased in oak species temporarily, whereas that in other species showed significantly increase in July (Figure I,2). The K concentrations in coarse roots of fir species and Scots pine decreased in July but that in the coarse roots of other species significantly increased (Figure 3). The P concentrations in all root diameters (except small root of Austrain pine) generally significantly decreased in all species over the study period (Figure I,2,3).

\section{Variation in microelement concentrations}

The concentrations of elements $(\mathrm{Pb}, \mathrm{Ni}, \mathrm{Mn}, \mathrm{Al}$, $\mathrm{Cu}, \mathrm{Fe}, \mathrm{Zn}$, and $\mathrm{Na}$ ) in the roots differed significantly between root diameters and species (Table 2). When the species were evaluated, it was seen that $\mathrm{Al}$ and Fe concentrations were higher than other element concentrations in all species (Table 4). In particular, the element concentrations in the fine roots were more than the small and coarse roots in all species (Table 4). 


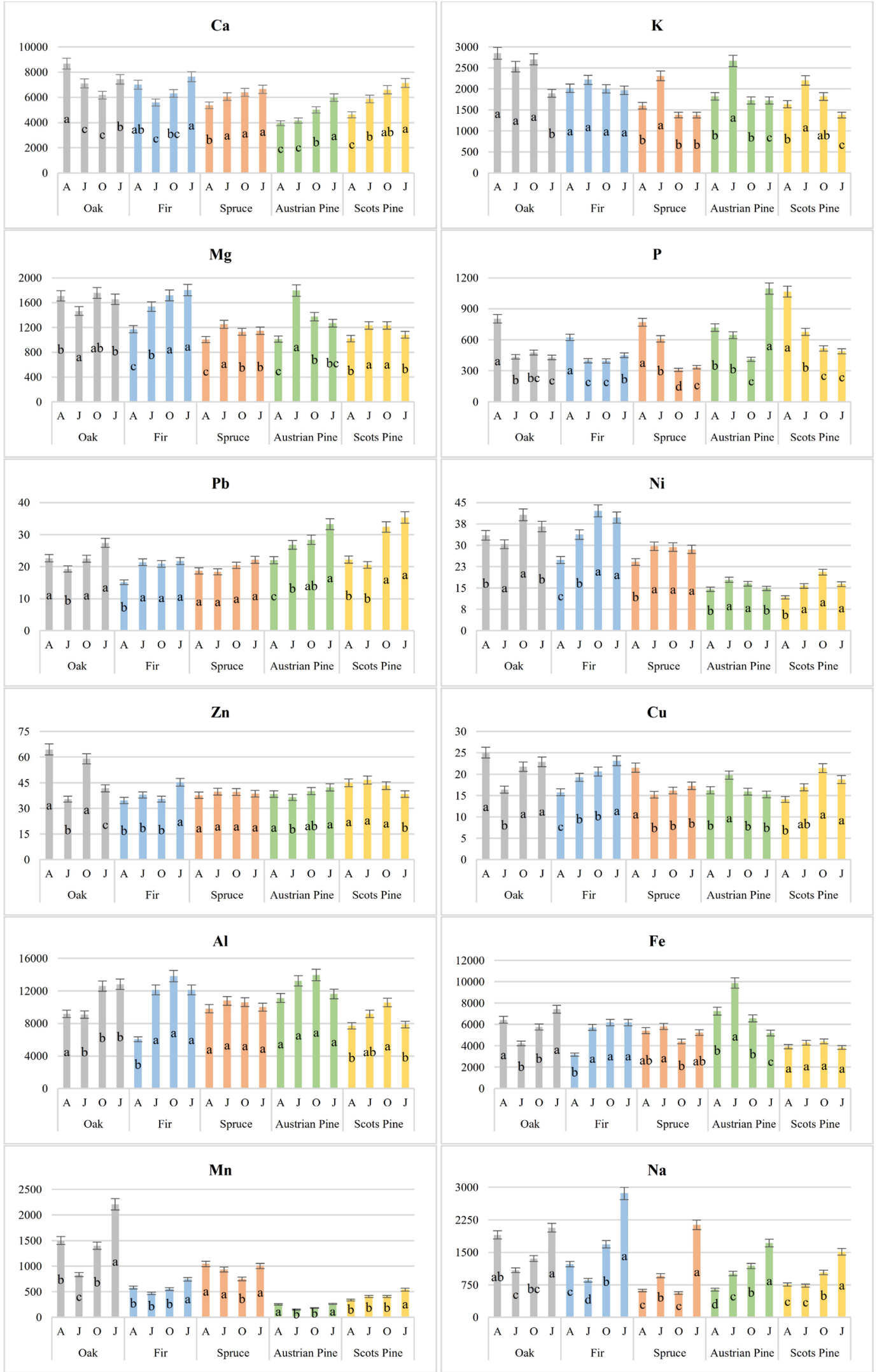

FIGURE I Seasonal variation of element concentration $\left(\mathrm{mg}^{\mathrm{k}} \cdot \mathrm{kg}^{-1}\right)$ in fine roots $(0-2 \mathrm{~mm})$. (Different letters indicate temporally significant differences in each species at $\mathrm{P}<0$ 0.05. The vertical bar is standard error.) . 


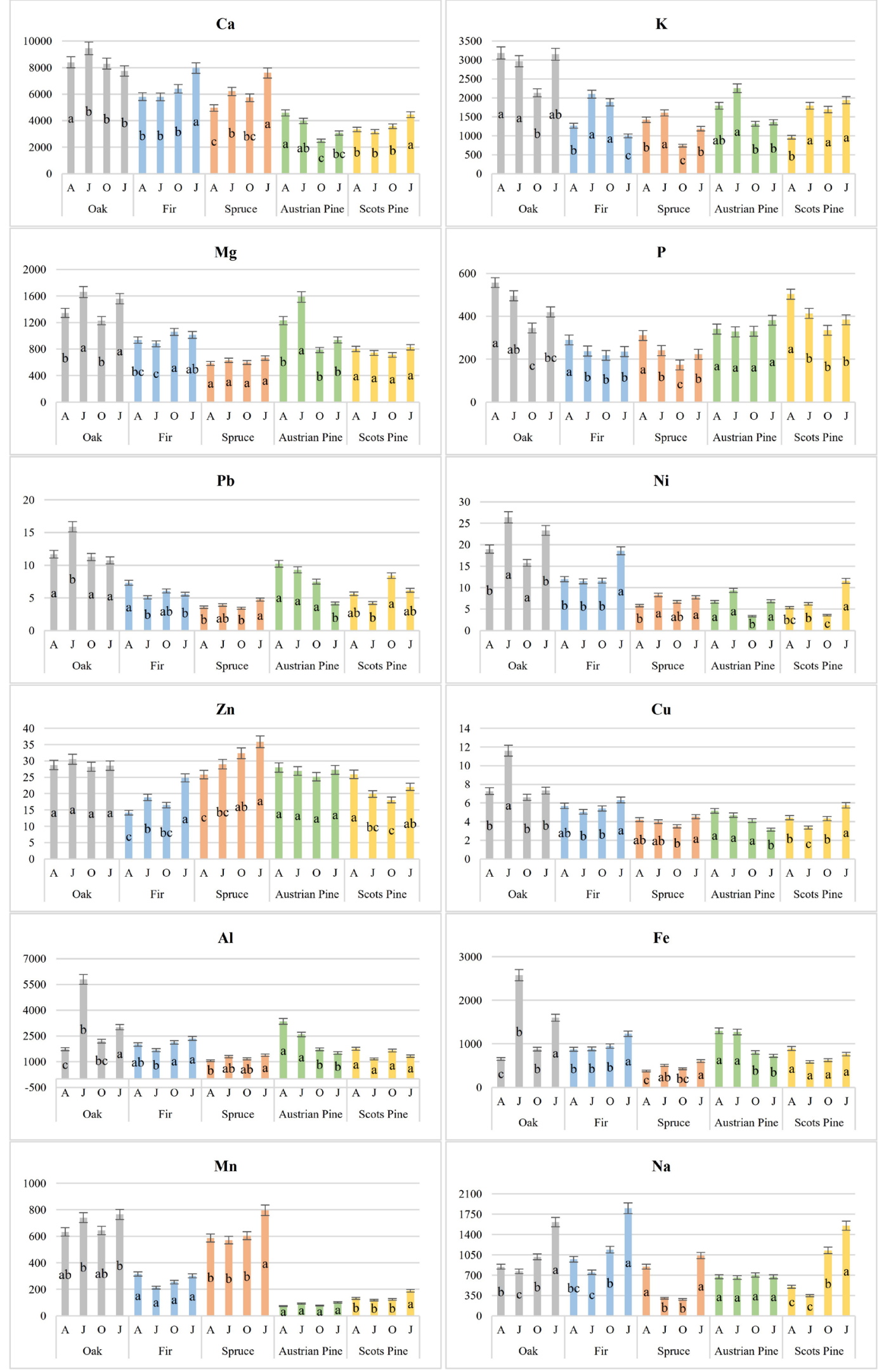

FIGURE 2 Seasonal variation of elements concentration $\left(\mathrm{mg}^{\prime} \cdot \mathrm{kg}^{-1}\right)$ in small roots $(2-5 \mathrm{~mm})$. (Different letters indicate temporally significant differences in each species at $\mathrm{P}<0.05$. The vertical bar is standard error.). 


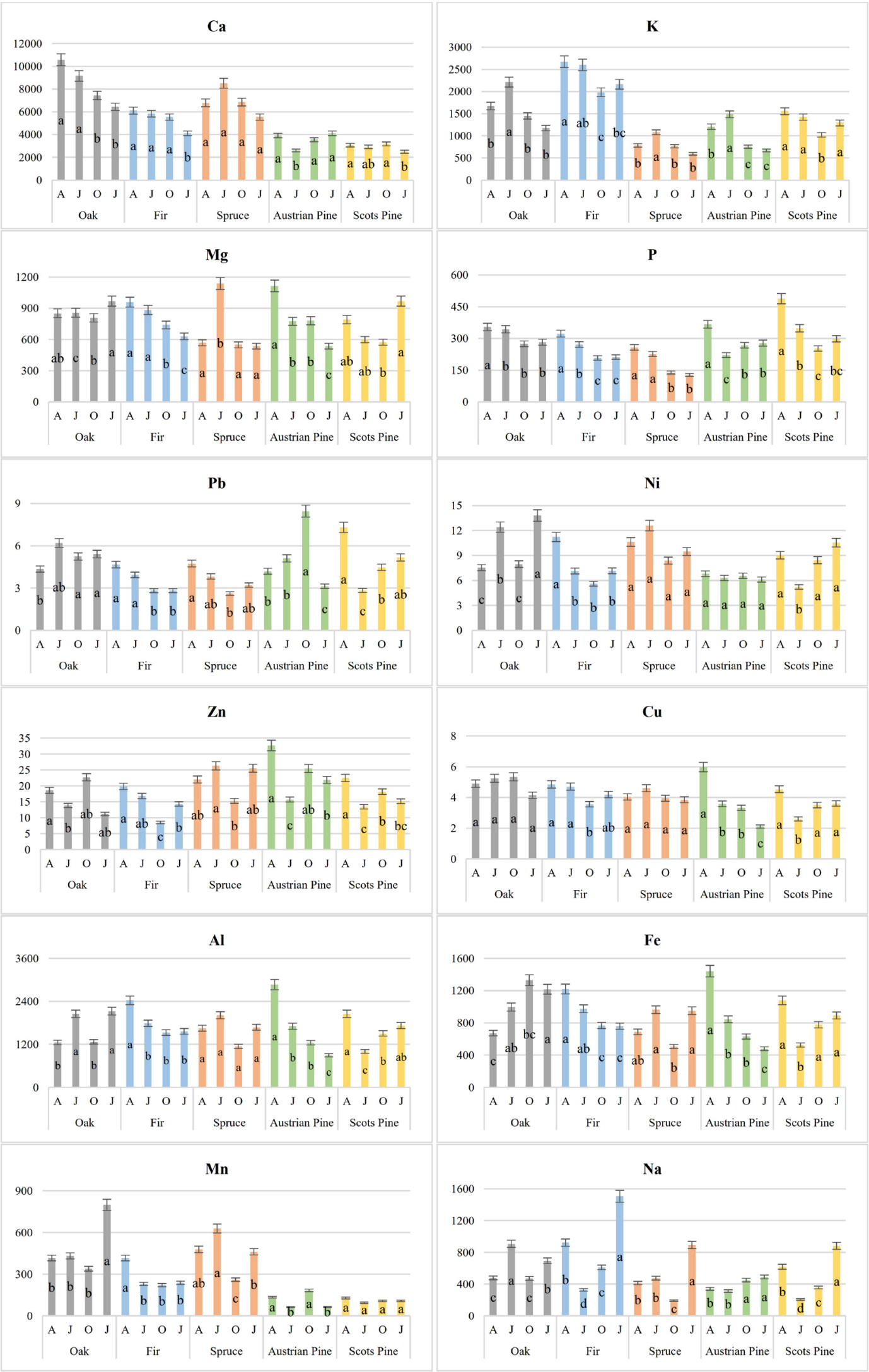

FIGURE 3 Seasonal variation of elements concentration $\left(\mathrm{mg}^{-1} \mathrm{~kg}^{-1}\right)$ in small roots $(2-5 \mathrm{~mm})$. (Different letters indicate temporally significant differences in each species at $\mathrm{P}<0.05$. The vertical bar is standard error.). 
TABLE 2 Statistical results from the multivariate analysis of variance (MANOVA) for variation of element concentration.

\begin{tabular}{|c|c|c|c|c|c|c|c|c|c|c|c|c|}
\hline Variable & $\mathrm{Ca}$ & $\mathrm{K}$ & $\mathrm{Mg}$ & $P$ & $\mathrm{~Pb}$ & $\mathrm{Ni}$ & $\mathrm{Al}$ & $\mathrm{Fe}$ & $\mathrm{Zn}$ & $\mathrm{Cu}$ & $\mathrm{Na}$ & $M n$ \\
\hline Time & 0.006 & 0.000 & 0.002 & 0.000 & 0.875 & 0.000 & 0.000 & 0.287 & 0.130 & 0.225 & 0.000 & 0.000 \\
\hline Species & 0.000 & 0.000 & 0.000 & 0.000 & 0.000 & 0.000 & 0.002 & 0.000 & 0.000 & 0.000 & 0.000 & 0.000 \\
\hline Root diameter & 0.000 & 0.000 & 0.000 & 0.000 & 0.000 & 0.000 & 0.000 & 0.000 & 0.000 & 0.000 & 0.000 & 0.000 \\
\hline Time $\times$ Species & 0.026 & 0.126 & 0.008 & 0.100 & 0.006 & 0.149 & 0.155 & 0.000 & 0.189 & 0.002 & 0.000 & 0.056 \\
\hline Time $\times$ Root diameter & 0.000 & 0.000 & 0.000 & 0.000 & 0.545 & 0.000 & 0.000 & 0.183 & 0.011 & 0.074 & 0.000 & 0.026 \\
\hline Species $\times$ Root diameter & 0.000 & 0.000 & 0.000 & 0.000 & 0.000 & 0.002 & 0.000 & 0.000 & 0.000 & 0.022 & 0.000 & 0.000 \\
\hline Time $\times$ Species $\times$ Root diameter & 0.006 & $0.07 \mid$ & 0.001 & 0.322 & 0.153 & 0.036 & 0.097 & 0.000 & 0.343 & 0.247 & 0.025 & 0.042 \\
\hline
\end{tabular}

Significant differences $(P \leq 0.05)$ are marked with italic

TABLE 3 Comparison of the mean element concentrations $\left(\mathrm{mg} \cdot \mathrm{kg}^{-1}\right)$ in different diameter classes of the roots in tree species.

\begin{tabular}{|c|c|c|c|c|c|c|c|c|c|}
\hline \multirow{2}{*}{$\begin{array}{l}\vec{y} \tilde{y} \\
\dot{\alpha} \frac{\pi}{v}\end{array}$} & \multirow{2}{*}{ Area } & \multicolumn{2}{|c|}{$\mathrm{Ca}$} & \multicolumn{2}{|c|}{$\mathrm{K}$} & \multicolumn{2}{|c|}{$\mathrm{Mg}$} & \multicolumn{2}{|c|}{$P$} \\
\hline & & Mean & $\pm \mathrm{Sd}$ & Mean & $\pm S d$ & Mean & $\pm S d$ & Mean & $\pm S d$ \\
\hline \multirow{5}{*}{$\begin{array}{l}\varepsilon \\
\text { Eิ } \\
\text { ऽ઼ }\end{array}$} & SO & $7346.0 c$ & 343.6 & $2494.8 \mathrm{~b}$ & 147.7 & $1646.8 \mathrm{c}$ & 69.57 & $536.5 \mathrm{ab}$ & 47.9 \\
\hline & TF & $6635.2 b c$ & 398.9 & $2051.5 a$ & 124.6 & $1556.9 \mathrm{bc}$ & 74.4 & $467.1 \mathrm{a}$ & 27.0 \\
\hline & OS & $6115.2 b$ & 835.2 & $1667.6 \mathrm{a}$ & 481.8 & $1132.7 \mathrm{a}$ & 135.9 & $506.7 \mathrm{a}$ & 213.4 \\
\hline & $\mathrm{AP}$ & $4777.8 \mathrm{a}$ & 984.6 & $1984.9 \mathrm{a}$ & 473.9 & $1362.9 b$ & 449.9 & $717.4 \mathrm{~b}$ & 259.9 \\
\hline & SP & $6056.9 \mathrm{~b}$ & 1648.9 & $1760.5 \mathrm{a}$ & 494.2 & $1141.4 \mathrm{a}$ & 188.1 & $687.5 \mathrm{~b}$ & 295.6 \\
\hline \multirow{5}{*}{$\begin{array}{l}E \\
\varepsilon \\
\stackrel{E}{\sim} \\
\tilde{\sim}\end{array}$} & SO & $8475.9 c$ & 619.9 & $2861.2 \mathrm{~b}$ & 148.3 & 1448.8d & 86.4 & $454.7 c$ & 31.9 \\
\hline & TF & $6493.9 \mathrm{~b}$ & 335.7 & $1564.3 \mathrm{a}$ & 150.8 & $971.8 c$ & 37.7 & $245.5 \mathrm{a}$ & 11.8 \\
\hline & OS & $6119.5 \mathrm{~b}$ & 1753.5 & $1238.7 \mathrm{a}$ & 530.8 & $618.6 \mathrm{a}$ & 127.5 & $236.7 \mathrm{a}$ & 66.6 \\
\hline & AP & $3531.2 \mathrm{a}$ & 1447.5 & 1682.1a & 892.8 & $1135.2 c$ & 598.5 & $345.0 \mathrm{~b}$ & 81.5 \\
\hline & SP & $3636.5 \mathrm{a}$ & 1149.9 & $1597.9 \mathrm{a}$ & 889.8 & $770.9 \mathrm{~b}$ & 213.9 & $408.7 \mathrm{bc}$ & 106.2 \\
\hline \multirow{5}{*}{$\begin{array}{l}V \\
\xi \\
\text { है }\end{array}$} & SO & $8405.5 c$ & 945.6 & $1627.6 c$ & 151.5 & $871.4 \mathrm{~b}$ & 47.7 & $313.7 \mathrm{bc}$ & 20.0 \\
\hline & TF & $5399.6 \mathrm{~b}$ & 429.8 & $2353.5 d$ & $14 \mid .5$ & $802.8 \mathrm{ab}$ & 44.1 & $253.4 \mathrm{bc}$ & 17.4 \\
\hline & OS & 6922. Ibc & 3464 & $805.9 a$ & 343.4 & $697.5 \mathrm{a}$ & 544.3 & $187.7 \mathrm{a}$ & 68.1 \\
\hline & $\mathrm{AP}$ & $3546.2 a$ & 1172.7 & $1028.7 a b$ & 487.3 & $801.3 \mathrm{ab}$ & 332.9 & $283.6 \mathrm{~b}$ & 74.7 \\
\hline & SP & $2917.9 \mathrm{a}$ & 759.4 & 1322.3bc & 653.3 & 733.2ab & 332.4 & $347.0 c$ & 132.3 \\
\hline
\end{tabular}

SO: Sessile Oak, TF: Turkish Fir, OS: Oriental Spruce, AP: Austrain Pine, SP:

Scots Pine, Sd: Standar deviation, Significant differences $(p \leq 0.05)$ between tree species are marked with different letters

$\mathrm{Pb}, \mathrm{Al}$, and $\mathrm{Fe}$ concentration in fine roots of oak were similar to those in the fine roots of coniferous species, although $\mathrm{Zn}$ and $\mathrm{Cu}$ concentrations were statistically higher in oak species than in coniferous species (Table 4). Mn concentration in fine roots was significantly different among species (Table 4).

With regard to element concentrations in small roots, oak species differed significantly in $\mathrm{Pb}, \mathrm{Cu}$, and $\mathrm{Ni}$ concentrations from other species, whereas fir species differed in $\mathrm{Ni}$ and $\mathrm{Cu}$ concentrations (Table 4). Fe concentration in both spruce and Scots pine was significantly different than those of other species (Table 4). Further, all species, except oak and spruce, were significantly different with regard to $\mathrm{Mn}$ concentration
(Table 4). Mn concentration in the coarse roots of the fir species differed statistically from other species (Table 4).

The elements, except $\mathrm{Pb}, \mathrm{Al}, \mathrm{Zn}$, and $\mathrm{Cu}$, showed temporal differences between species depending on the root diameters (Table 2). When the fine roots were evaluated according to species, oak species showed a significantly decrease in all microelements during July (Figure I). In addition, $\mathrm{Fe}, \mathrm{Cu}, \mathrm{Ni}$, and $\mathrm{Pb}$ concentrations in fine roots of fir species and austrain pine showed significantly increase during the study period (Figure I). The element concentrations, excluding $\mathrm{Na}$ and $\mathrm{Zn}$, for small roots reached significantly highest level in the oak species in July, as opposed to the decrease in concentration for fine roots (Figure 2). According to species, concentrations in coarse roots showed a temporarily different fluctuation (Figure 3). In particular, $\mathrm{Al}, \mathrm{Fe}$, and $\mathrm{Cu}$ concentrations significantly decreased in Austrian pine over the study period (Figure I,2,3).

\section{Relationships between element concentrations}

On evaluating the relationships between elements in fine roots, there was a significant negative correlation among $\mathrm{Mn}, \mathrm{Pb}$, and $\mathrm{K}$ and between $\mathrm{Al}$ and $\mathrm{Ca}$ in oak species; between $\mathrm{Ni}$ and $\mathrm{P}$ in spruce species; between $\mathrm{Al}$ and $\mathrm{P}$ and $\mathrm{Fe}$ and $\mathrm{o}=$ in the Austrian pine; among $\mathrm{Pb}, \mathrm{Ni}, \mathrm{Al}, \mathrm{Fe}$, and $\mathrm{P}$ and between $\mathrm{Pb}$ and $\mathrm{K}$ in fir species; and among $\mathrm{Pb}, \mathrm{Mn}$, and $\mathrm{K}$ and among $\mathrm{Pb}, \mathrm{Ni}, \mathrm{Al}$, and $P$ in Scots pine (Table 5). Furthermore, there were less significant relationships in spruce species and more significant relationships in fir species (Table 5).

TABLE 4 Comparison of the mean micro element concentrations $\left(\mathrm{mg}^{\mathrm{kg}} \mathrm{kg}^{-1}\right)$ in different diameter classes of the roots in tree species.

\begin{tabular}{|c|c|c|c|c|c|c|c|c|c|c|c|c|c|c|c|}
\hline \multirow{2}{*}{ 苂总 } & & \multicolumn{2}{|c|}{$\mathrm{Pb}$} & \multicolumn{2}{|c|}{$\mathrm{Ni}$} & \multicolumn{2}{|c|}{$\mathrm{Al}$} & \multicolumn{2}{|c|}{$\mathrm{Fe}$} & \multicolumn{2}{|c|}{$\mathrm{Zn}$} & \multicolumn{2}{|c|}{$\mathrm{Cu}$} & $M n$ & $\mathrm{Na}$ \\
\hline & & Mean & $\pm S d$ & Mean & $\pm \mathrm{Sd}$ & Mean & $\pm S d$ & Mean & \pm Sd & Mean & $\pm S d$ & Mean & $\pm \mathrm{Sd}$ & Mean & Mean \\
\hline & 50 & $22.9 \mathrm{ab}$ & 2.02 & $35.3 c$ & 1.42 & $0916.4 \mathrm{ab}$ & 636.4 & $961.9 \mathrm{~b}$ & 530.4 & $50.2 b$ & 9.95 & $21.5 \mathrm{~b}$ & 1.1 & $1485.3 \mathrm{e} \quad 137.9$ & $601.6 \mathrm{~b}$ \\
\hline & $\mathrm{TF}$ & $19.8 \mathrm{a}$ & 1.2 & $35.1 \mathrm{c}$ & 2.0 & $11032.1 \mathrm{~b}$ & 923.9 & $5315.5 \mathrm{ab}$ & 413.3 & $38.3 a$ & 2.1 & $19.7 a b$ & 0.9 & $\begin{array}{ll}585.5 c & 47.6 \\
\end{array}$ & $1657.2 \mathrm{~b} \quad 212.9$ \\
\hline & OS & $19.9 \mathrm{a}$ & 7.2 & $27.9 b$ & 4.3 & 10296.7ab & 1854.8 & $5214.4 \mathrm{ab}$ & 1297.2 & $38.9 a$ & 10.4 & $17.6 \mathrm{a}$ & 4.2 & 933.0d 204.9 & $1068.1 \mathrm{a} \quad 688.1$ \\
\hline & $\mathrm{AP}$ & $27.6 \mathrm{~b}$ & 6.7 & $15.9 a$ & 2.3 & $12477.3 \mathrm{~b}$ & 3247.5 & $7222.4 c$ & 2377.7 & $39.3 a$ & 6.1 & $16.8 \mathrm{a}$ & 3.1 & $213.4 a$ & $1137.6 \mathrm{ab} \quad 428.6$ \\
\hline & SP & $27.6 \mathrm{~b}$ & 10.4 & $16.1 \mathrm{a}$ & 5.7 & $8827.7 a$ & 2659.6 & $4 I I 5.3 a$ & 1010.6 & $43.3 \mathrm{ab}$ & 6.6 & $17.8 \mathrm{a}$ & 6.5 & $424.1 \mathrm{~b}$ & $1010.4 \mathrm{a}$ \\
\hline \multirow{5}{*}{ 占 } & SO & $12.4 \mathrm{c}$ & 1.2 & $21.1 \mathrm{c}$ & 2.1 & 318 & 441.7 & $1427.5 c$ & 212.9 & $29.1 \mathrm{~b}$ & 2.9 & $8.2 c$ & 0.6 & $695.3 d \quad 45.9$ & $1060.2 b c \quad 133.1$ \\
\hline & TF & $6.0 \mathrm{~b}$ & 0.5 & $13.4 \mathrm{~b}$ & 1.4 & $2034.4 b$ & 139.9 & $985.8 c$ & 68.1 & 18 & I. & 5.6 & 0.2 & 25.7 & $1178.2 c \quad 136.5$ \\
\hline & OS & $3.9 \mathrm{a}$ & 1.37 & $7.1 \mathrm{a}$ & 2.53 & $1.5 \mathrm{a}$ & 376.7 & $478.5 a$ & 149.4 & $30.8 \mathrm{~b}$ & 8.2 & 4.Ia & 1.1 & $639.4 d \quad 184.6$ & $617.2 a$ \\
\hline & AP & $7.8 b$ & 4.78 & $6.6 a$ & 4.93 & $2288.7 b$ & 1240.2 & $1023.9 c$ & 522.7 & $26.9 b$ & 5.8 & $4.3 a$ & 1.5 & $86.2 a$ & 677.6ab 247.I \\
\hline & SP & $6.1 \mathrm{~b}$ & 4.13 & $6.7 \mathrm{a}$ & 4.18 & $1470.4 a$ & 765.3 & $716.9 b$ & 379.8 & $21.5 a$ & 5.8 & $4.5 \mathrm{a}$ & 1.3 & $140.5 b$ & 881.9abc 748.8 \\
\hline & SO & $5.3 c$ & 0.4 & $10.4 \mathrm{~b}$ & 0.9 & & 1446 & & 219.2 & $16.6 \mathrm{a}$ & 3.5 & & 0. & 71.9 & $637.7 a b$ \\
\hline & TF & $3.6 \mathrm{a}$ & 0.4 & $7.8 \mathrm{ab}$ & 0.9 & $1827.3 a$ & 180.2 & $1827.3 \mathrm{a}$ & 97.7 & $14.9 \mathrm{a}$ & 1.6 & $4.3 \mathrm{ab}$ & 0.3 & $275.9 b$ & $841.4 b$ \\
\hline & OS & $3.6 a b$ & 2.4 & $10.3 a b$ & 7.3 & $1619.7 \mathrm{a}$ & 951.6 & $777.3 a$ & 433.6 & $22.3 \mathrm{~b}$ & 11.6 & 4.Iab & 1.6 & $457.2 c \quad 194.5$ & $493.2 a$ \\
\hline & AP & $5.2 b c$ & 3.1 & $6.5 \mathrm{a}$ & 1.9 & $1677.7 \mathrm{a}$ & 1005.1 & $848.7 a$ & 485.8 & $23.9 \mathrm{~b}$ & 9.8 & $3.7 \mathrm{a}$ & 2.3 & $110.9 \mathrm{a}$ & $397.4 a$ \\
\hline & SP & $4.9 \mathrm{bc}$ & 2.7 & 8.3ab & 3.8 & $1570.3 a$ & 657.4 & $818.2 a$ & 380.1 & $17.3 \mathrm{ab}$ & 5.4 & $3.6 \mathrm{a}$ & 1.2 & $109.2 \mathrm{a}$ & $515.9 a$ \\
\hline
\end{tabular}

SO: Sessile Oak, TF: Turkish Fir, OS: Oriental Spruce, AP: Austrain Pine, SP: Scots Pine, Sd: Standar deviation, Significant differences ( $\mathrm{P} \leq 0.05)$ between tree

species are marked with different letters. 
TABLE 5 Releationship between concentration of elements in fine root according to tree species.

\begin{tabular}{|c|c|c|c|c|c|c|c|c|}
\hline & & $\mathrm{Pb}$ & $\mathrm{Ni}$ & $\mathrm{Al}$ & $\mathrm{Fe}$ & $\mathrm{Ca}$ & K & $M n$ \\
\hline \multirow{7}{*}{ SO } & $\mathrm{Ni}$ & -0.23 & & & & & & \\
\hline & $\mathrm{Al}$ & 0.51 & 0.42 & & & & & \\
\hline & $\mathrm{Fe}$ & 0.67 & -0.01 & 0.64 & & & & \\
\hline & $\mathrm{Ca}$ & -0.36 & 0.08 & -0.52 & -0.12 & & & \\
\hline & $\mathrm{K}$ & -0.51 & 0.36 & -0.17 & -0.25 & 0.37 & & \\
\hline & $\mathrm{Mn}$ & 0.42 & 0.16 & 0.46 & 0.64 & 0.10 & -0.46 & \\
\hline & P & -0.22 & 0.08 & -0.25 & 0.00 & 0.45 & 0.49 & -0.19 \\
\hline \multirow{7}{*}{ TF } & $\mathrm{Ni}$ & 0.56 & & & & & & \\
\hline & $\mathrm{Al}$ & 0.60 & 0.78 & & & & & \\
\hline & $\mathrm{Fe}$ & 0.59 & 0.76 & 0.97 & & & & \\
\hline & $\mathrm{Ca}$ & -0.08 & 0.28 & 0.08 & 0.11 & & & \\
\hline & $\mathrm{K}$ & -0.43 & -0.26 & -0.05 & -0.05 & -0.37 & & \\
\hline & $\mathrm{Mn}$ & 0.19 & 0.39 & -0.04 & 0.13 & 0.38 & -0.38 & \\
\hline & P & -0.56 & -0.42 & -0.64 & -0.62 & 0.64 & -0.16 & 0.18 \\
\hline \multirow{7}{*}{ OS } & $\mathrm{Ni}$ & 0.11 & & & & & & \\
\hline & $\mathrm{Al}$ & 0.33 & 0.75 & & & & & \\
\hline & $\mathrm{Fe}$ & 0.22 & 0.47 & 0.76 & & & & \\
\hline & $\mathrm{Ca}$ & -0.24 & 0.17 & -0.12 & -0.27 & & & \\
\hline & $\mathrm{K}$ & 0.02 & 0.32 & 0.38 & 0.64 & -0.08 & & \\
\hline & $M n$ & -0.08 & -0.13 & -0.05 & 0.13 & 0.01 & 0.03 & \\
\hline & $P$ & 0.01 & -0.44 & -0.16 & 0.23 & -0.55 & 0.47 & 0.27 \\
\hline \multirow{7}{*}{ AP } & $\mathrm{Ni}$ & -0.11 & & & & & & \\
\hline & $\mathrm{Al}$ & 0.21 & 0.07 & & & & & \\
\hline & $\mathrm{Fe}$ & -0.51 & 0.71 & 0.24 & & & & \\
\hline & $\mathrm{Ca}$ & 0.47 & -0.11 & -0.13 & -0.52 & & & \\
\hline & $\mathrm{K}$ & -0.28 & 0.50 & 0.22 & 0.78 & -0.30 & & \\
\hline & $M n$ & 0.04 & -0.06 & -0.03 & -0.12 & 0.44 & -0.18 & \\
\hline & $P$ & 0.30 & -0.28 & -0.47 & -0.35 & 0.45 & -0.09 & 0.38 \\
\hline \multirow{7}{*}{ SP } & $\mathrm{Ni}$ & 0.44 & & & & & & \\
\hline & $\mathrm{Al}$ & 0.20 & 0.65 & & & & & \\
\hline & $\mathrm{Fe}$ & 0.09 & 0.62 & 0.87 & & & & \\
\hline & $\mathrm{Ca}$ & 0.18 & 0.40 & -0.23 & -0.11 & & & \\
\hline & $\mathrm{K}$ & -0.43 & 0.19 & 0.53 & 0.48 & -0.21 & & \\
\hline & $\mathrm{Mn}$ & 0.28 & 0.43 & -0.18 & -0.24 & 0.55 & -0.53 & \\
\hline & $P$ & -0.58 & -0.62 & -0.42 & -0.25 & -0.28 & -0.05 & -0.19 \\
\hline
\end{tabular}

SO: Sessile Oak, TF: Turkish Fir, OS: Oriental Spruce, AP: Austrian Pine, SP: Scots Pine, Significant differences $(p \leq 0.05)$ are marked with italic

There is no significant negative correlation between the species for the elements in the small roots. However, there were less significant correlations in the oak species and more significant relationships in Austrian pine and Scots pine species. The inter-elemental relationship in the coarse roots was similar to those in the small roots. Only, there was a negative correlation between $\mathrm{Pb}$ and $\mathrm{Ca}$ and between $\mathrm{Fe}$ and $\mathrm{Mg}$, $\mathrm{Ca}$ in oak species.

\section{DISCUSSION}

\section{Variation in macroelement concentrations}

The nutrient concentrations between different tree organs are very variable and they incline to be higher in the growing parts of trees (Hellsten et al., 20I3). In this study, $\mathrm{Mg}, \mathrm{K}$, and $\mathrm{P}$ concentrations showed a tendency to decrease as the root diameter increases in all species. Similar to our results, Augusto et al. (2015), Ranger and Gelhaye (200 I), Yuan et al. (20I I)and Lemma et al. (2007) showed higher level of $\mathrm{Mg}$, $\mathrm{P}$, and $\mathrm{K}$ in fine roots. In addition, $\mathrm{Ca}$ concentration in oak, and spruce species tended to be high with increasing root diameter in this study. However, a contrasting situation was seen in Austrian pine, Scots pine and fir probably because of the differences in the morphological structure of these species. Chen et al. (20/3) found that root tissue density was higher the angiosperm species than coniferous species. Also, Tecimen and Makineci (2007) stated that the level of nutrients in woody tissues of conifers was lower than deciduous species. In present study, the decreasing $\mathrm{Ca}$ concentration in Austrian and Scots pine can be explained by differences of root tissue density. The root properties of plants (tissue density, diameter etc.) may also affect the rate of tissues decomposition (Beidler and Pritchard, 2017). Consequently, it could said that differences of element concentration in root diameter classes of species would potentially to be different effect in below ground biogeochemical cycles at same site conditions.

The temporal change of macroelement concentrations ( $\mathrm{Ca}, \mathrm{K}$ and $\mathrm{Mg}$ ) in the fine roots generally resulted in a decrease in the oak species in July. The concentration of these elements increased in coniferous species during this period. When small roots were evaluated, $\mathrm{Ca}$ and $\mathrm{Mg}$ concentration increased in oak species during this period but decreased in fir, Austrian pine (excluding $\mathrm{Mg}$ ), and Scots pine species. This may be because of the translocations from fine roots to small roots which is highly depending on rapid root growth in oak species during this period, which is the period of active growth. However, Withington et al. (2006) stated that angiosperm roots tended to faster growth than coniferous roots.

For oak species, $\mathrm{K}$ concentration decreased in small roots, whereas that in coarse roots increased. For this situation, it can be presumed that this was because of the translocation of $\mathrm{K}$ from fine and small roots to coarse roots in oak species. However, although $\mathrm{K}$ concentration in small and coarse roots of Austrian pine and spruce species were observed to increase, there was a decrease in the concentration in Scots pine and fir species. Here it can be interpreted that although $\mathrm{K}$ is mobile (White, 20I2), the Austrian pine and spruce species translocate $\mathrm{K}$ more slowly to the above-ground organs than Scots pine and fir species. Likewise, temporal changes in $\mathrm{P}$ concentration generally follow a decreasing trend in all root diameters and species. This may be because of fast translocation of $P$ to the above-ground growth organs (such as leaves and fruits) owing to the high mobility of the $\mathrm{P}$ element in the plant as stated by Zhao et al. (20I6). 
The macroelements ( $\mathrm{Ca}$ and $\mathrm{Mg}$ ) temporarily showed significant differences between species depending on the root diameters. Yin et al. (199I) found that $\mathrm{Ca}$ and $\mathrm{Mg}$ show a significant temporal change. They emphasized that this significant change is the result of the active interactions of many processes such as translocation, absorption of nutrients, interstitial accumulation, and root growth. Especially, oak species had a tendency with higher changes than coniferous species in present study. Mueller et al. (2010) pointed out that rapid growing root is more common in angiosperm species. Also, there are certain genotypic differences in the ability of different plants to take up and translocate various elements as stated by Shtangeeva et al. (2009). Consequently, the differences in $\mathrm{Ca}$ and $\mathrm{Mg}$ concentration owing to temporal change in present study can be explained by these abovementioned factors.

\section{Variation in microelement concentrations}

On evaluating microelements in the fine roots among species, all microelements in the oak species showed a tendency to decrease in July. This situation may be because the translocation rate is higher in the oak species during this period, which is the period of active growth, as indicated in the section on macroelements. When the small roots were evaluated, it was found that microelement concentrations (except to $\mathrm{Na}$ and $\mathrm{Zn}$ ) increased during this period. This suggests that although the mobility of micro elements is low, they can be translocated from the fine roots to the small roots. Moreover, $\mathrm{Fe}, \mathrm{Cu}, \mathrm{Ni}$, and $\mathrm{Pb}$ concentration in fine roots of fir species increased during the study period. This may be because these elements are antagonistic to $P$ element. Similar to this study, Păhlsson (1989) emphasizes the contrasting relation between microelements and macroelements, especially $\mathrm{Ca}, \mathrm{P}$, and $\mathrm{Mg}$. The temporal changes in microelements in coarse roots showed varying fluctuations for different species. However, Al, $\mathrm{Fe}$, and $\mathrm{Cu}$ has a prominent tendency to decrease in the Austrian pine species over the study period. This may be because of the low mobility of these elements in plant, and also because the translocation activity in these species is lower than that in other species.

All elements, except $\mathrm{Pb}, \mathrm{Al}, \mathrm{Zn}$, and $\mathrm{Cu}$, have temporal differences between species according to their root diameters. Further, it was determined that a given species shows a significant difference in terms of micro element concentration. This difference between species may result from differences in the morphological structure of the roots, differences in microorganisms in the roots (especially mycorrhizal fungi), and differences in the physiology and biochemistry of the nutrients in the roots (Pallardy, 2008). Ayhan et al. (2006) stated that metal intake varies depending on the plant species and that the properties such as root cation exchange capacity and root surface area affect metal uptake. In addition, there are studies showing that elements such as $\mathrm{Al}, \mathrm{Ni}$, $\mathrm{Cu}, \mathrm{Zn}$, and $\mathrm{Pb}$ are prevented from being transported to the upper organs by mycorrhizal fungi (Dahlgren et al., 1991; Moyer-Henry et al., 2005; Wilkins, 1991).

\section{Relationships between elements concentrations}

Macro elements ( $\mathrm{Ca}, \mathrm{P}$ and $\mathrm{Mg}$ ) have antagonistic affect against absorption micro elements (Kabata-Pendias, 20I0). In this study, There is different negative correlation between microelements ( $\mathrm{Pb}, \mathrm{Mn}, \mathrm{Ni} \mathrm{Al}$, and $\mathrm{Fe}$ ) and macroelements $(\mathrm{Ca}, \mathrm{K}$, and $\mathrm{P})$ in fine roots depending on the species. Similar to the results of this study, previous studies have shown that microelements are negatively associated with macroelements such as $\mathrm{Ca}, \mathrm{K}, \mathrm{P}$, and $\mathrm{Mg}$ (Brunner et al., 2008; Buschmann et al., 1991; Heim et al., 1999; Kahle, 1993; Påhlsson, 1989). Brunner et al. (2002) pointed out that differences of soil types are more effective than differences of tree species on fine root chemistry. On the contrary, these different relationships in present study may be the result of different morphological properties in tree species rather than soil type.

In terms of inter-elemental relationships in small roots of all species, there was no significant negative correlation. However, although the relationship in the oak species was weaker, there was a stronger relationship both Austrian pine and Scots pine. Elemental relationships in coarse roots are similar to those in small roots. A negative correlation was only observed between $\mathrm{Pb}$ and $\mathrm{Ca}$ and $\mathrm{Fe}$ and $\mathrm{Mg}$ in oak species. The cell walls of plant are very effective in the immobilization of metals, and therefore, serve as a storage space for metals (Brunner and Frey, 2000; Kahle, 1993). In this study, when the interactions were taken into consideration, it is thought that $\mathrm{Al}$ pass to $\mathrm{Ca}$ sites in oak roots. Consequently, there can be an accumulation of $\mathrm{Al}$ in cell walls and plasma membranes as stated by Kochian et al. (2005). Likewise, it can be assumed that $\mathrm{Al}$ was replaced with phosphate compounds in the cell walls of Austrian pine, Scots pine and fir roots.. It is possible to say that elements are stored with different mechanisms according to the species and that the elements are transported to other organs differently. These processes are controlled by both genetic characteristics and environmental conditions (Yin et al., 1991). 


\section{CONCLUSION}

In conclusion, macro and micro nutrient concentrations decreased with increasing root diameter. It was seen that the oak, which is a natural species, had a higher element concentration than coniferous plantations in all root diameters. In addition, it can be expressed that oak species carries out a higher translocation process than coniferous species over the growth period. The fine roots in coniferous species had different negative correlation between microelement and macroelements different from oak species. However, as the striking result of the study, Fe concentration of coarse roots of oak species showed antagonistic interaction with $\mathrm{Mg}$ and $\mathrm{Ca}$ but there were not antagonistic interactions in the coniferous species.

Consequently, the study, which is a short-term, results showed that different species had different nutritional and nutrient storage properties at the same site. Although previous studies have focused on fine roots, studies on small and coarse roots are few. To better understand nutrient intake and storage mechanisms of trees with regard to belowground organs, long-term observation of different species and different sites, combined with protein analysis of the elements is required. This will guide the assessment of the nutrition and growth relationships in natural and plantation areas.

\section{ACKNOWLEDGMENT}

This work was supported by the Scientific Research Projects Coordination Unit of Istanbul University-Cerrahpasa, Project number: FYO-201727635. It was presented as a oral presentation titled "Temporal Variations of Elements Stocks in Fine Roots Under Different Tree Species", and its abstract was published in the abstracts book of the Symposium "International Ecology 2018 Symposium " in Kastamonu, Turkey, 19-23 June 2018. I thank to Ender Makineci for his valuable help and recommendations.

\section{References}

AERTS, R.; CHAPIN III, F.S. The mineral nutrition of wild plants revisited: a re-evaluation of processes and patterns, Advances in Ecological Research. Elsevier, 1999. p. I-67.

AKBURAK, S.; MAKINECI, E. Temporal changes of soil respiration under different tree species. Environmental monitoring and assessment, v. I85, n.4, p.3349-3358, 2013.

AKBURAK, S.; ORAL, H.V.; OZDEMIR, E.; MAKINECI, E. Temporal variations of biomass, carbon and nitrogen of roots under different tree species. Scandinavian journal of forest research, v.28, n.I, p.8-16, 2013.
ASSEFA, D.; GODBOLD, D.L.; BELAY, B.; ABIYU, A.; REWALD, B. Fine Root Morphology, Biochemistry and Litter Quality Indices of Fast-and Slow-growing Woody Species in Ethiopian Highland Forest. Ecosystems, v.2I, n.3, p.482-494, 2018.

AUGUSTO, L.; ACHAT, D.L.; BAKKER, M.R.; BERNIER, F.; BERT, D.; DANJON, F.; KHLIFA, R.; MEREDIEU, C.; TRICHET, $\mathrm{P}$. Biomass and nutrients in tree root systems-sustainable harvesting of an intensively managed Pinus pinaster (Ait.) planted forest. Gcb Bioenergy, v.7, n.2, p.23I-243, 20 I 5.

AYHAN, B.; EKMEKÇI, Y.; TANYOLAÇ, D. Bitkilerde ağır metal zararları ve korunma mekanizmaları. Anadolu Unuversity Journal of Science and Technology, v.7, n. I, p. I- I6, 2006.

BARDGETT, R.D.; MOMMER, L.; DE VRIES, FT. Going underground: root traits as drivers of ecosystem processes. Trends in Ecology \& Evolution, v.29, n. 12, p.692-699, 2014.

BEIDLER, K.V.; PRITCHARD, S.G. Maintaining connectivity: Understanding the role of root order and mycelial networks in fine root decomposition of woody plants. Plant and soil, v.420, n.I-2, p.19-36, 2017.

BLOOMFIELD, J. Tree root turnover and senescence. Plant roots: The hidden half, p.363-38I, 1996.

BRUNNER, I.; BRODBECK, S.; WALTHERT, L. Fine root chemistry, starch concentration, and 'vitality' of subalpine conifer forests in relation to soil $\mathrm{pH}$. Forest Ecology and Management, v. I65, n. I-3, p.75-84, 2002.

BRUNNER, I.; FREY, B. Detection and localization of aluminum and heavy metals in ectomycorrhizal Norway spruce seedlings. Environmental Pollution, v.108, n.2, p.121-128, 2000.

BRUNNER, I.; HERZOG, C.; DAWES, M.A.; AREND, M.; SPERISEN, C. How tree roots respond to drought. Frontiers in plant science, v.6, p.547, 2015.

BRUNNER, I.; LUSTER, J.; GÜNTHARDT-GOERG, M.S.; FREY, B. Heavy metal accumulation and phytostabilisation potential of tree fine roots in a contaminated soil. Environmental Pollution, v. I52, n.3, p.559-568, 2008.

BUSCHMANN, B.; KAHLE, H.; BRECKLE, S. Zum Einfluß von Cadmium auf Mineralstoffhaushalt und Vegetationszeit von Buchenjungwuchs auf verschiedenen Substraten. Verhandlungen Gesellschaft Ökologie, v. 19, n.3, p.209213, 1991.

CHEN, H.; DONG, Y.; XU, T.; WANG, Y.; WANG, H.; DUAN, $B$. Root order-dependent seasonal dynamics in the carbon and nitrogen chemistry of poplar fine roots. New forests, v.48, n.5, p.587-607, 2017.

CHEN, W.; ZENG, H.; EISSENSTAT, D.M.; GUO, D. Variation of first-order root traits across climatic gradients and evolutionary trends in geological time. Global Ecology and Biogeography, v.22, n.7, p.846-856, 2013. 
ÇAKIR, M.; AKBURAK, S. Litterfall and nutrients return to soil in pure and mixed stands of oak and beech. Journal of the Faculty of Forestry Istanbul University, v.67, n.2, p.185200, 2017.

DAHLGREN, R.A.; VOGT, K.A.; UGOLINI, F.C. The influence of soil chemistry on fine root aluminum concentrations and root dynamics in a subalpine Spodosol, Washington State, USA. Plant and Soil, v.133, n. I, p. I17-129, I991.

FORTIER, J.; TRUAX, B.; GAGNON, D.; LAMBERT, F. Plastic allometry in coarse root biomass of mature hybrid poplar plantations. BioEnergy Research, v.8, n.4, p. I69I-I704, 2015.

GORDON, W.S.; JACKSON, R.B. Nutrient concentrations in fine roots. Ecology, v.8I, n. I, p.275-280, 2000.

GUO, L.; CHEN, J.; CUI, X.; FAN, B.; LIN, H. Application of ground penetrating radar for coarse root detection and quantification: a review. Plant and soil, v.362, n. I-2, p.I$23,2013$.

HAN, S.H.; KIM, S.; CHANG, H.; KIM, H.-J.; KHAMZINA, A.; SON, Y. Soil depth-and root diameter-related variations affect root decomposition in temperate pine and oak forests. Journal of Plant Ecology, 2019.

HEIM, A.; LUSTER, J.; BRUNNER, I.; FREY, B.; FROSSARD, E. Effects of aluminium treatment on Norway spruce roots: aluminium binding forms, element distribution, and release of organic substances. Plant and Soil, v.216, n. I-2, p. 103-I 16, 1999.

HELLSTEN, S.; HELMISAARI, H.-S.; MELIN, Y.; SKOVSGAARD, J.P.; KAAKINEN, S.; KUKKOLA, M.; SAARSALMI, A.; PETERSSON, H.; AKSELSSON, C. Nutrient concentrations in stumps and coarse roots of Norway spruce, Scots pine and silver birch in Sweden, Finland and Denmark. Forest Ecology and Management, v.290, p.40-48, 2013.

HELMISAARI, H.S. Variation in nutrient concentrations of Pinus sylvestris roots, Developments in Agricultural and Managed Forest Ecology. Elsevier, 1991. p. 204-212.

HOBBIE, S.E.; OLEKSYN, J.; EISSENSTAT, D.M.; REICH, P.B. Fine root decomposition rates do not mirror those of leaf litter among temperate tree species. Oecologia, v.162, n.2, p.505-5I3, 2010.

IIVONEN, S.; KAAKINEN, S.; JOLKKONEN, A.; VAPAAVUORI, E.; LINDER, S. Influence of long-term nutrient optimization on biomass, carbon, and nitrogen acquisition and allocation in Norway spruce. Canadian Journal of Forest Research, v.36, n.6, p.I563-I57I, 2006.

INAGAKI, M.; INAGAKI, Y.; KAMO, K.; TITIN, J. Fine-root production in response to nutrient application at three forest plantations in Sabah, Malaysia: higher nitrogen and phosphorus demand by Acacia mangium. Journal of forest research, v. I4, n.3, p. I78-182, 2009.

KABATA-PENDIAS, A. Trace Elements in Soils and Plants. CRC Press, Boca Raton, 2010.
KAHLE, H. Response of roots of trees to heavy metals. Environmental and Experimental Botany, v.33, n.l, p.99-119, 1993.

KOCHIAN, L.V.; PINEROS, M.A.; HOEKENGA, O.A. The physiology, genetics and molecular biology of plant aluminum resistance and toxicity, Root physiology: from gene to function. Springer, 2005. p. I75- 195.

LEHMANN, J.; ZECH, W. Fine root turnover of irrigated hedgerow intercropping in Northern Kenya. Plant and Soil, v. 198, n. I, p.19-31, 1998.

LEMMA, B.; NILSSON, I.; KLEJA, D.B.; OLSSON, M.; KNICKER, $H$. Decomposition and substrate quality of leaf litters and fine roots from three exotic plantations and a native forest in the southwestern highlands of Ethiopia. Soil Biology and Biochemistry, v.39, n.9, p.23 I 7-2328, 2007.

LISKI, J.; KAASALAINEN, S.; RAUMONEN, P.; AKUJÄRVI, A.; KROOKS, A.; REPO, A.; KAASALAINEN, M. Indirect emissions of forest bioenergy: detailed modeling of stumproot systems. Gcb Bioenergy, v.6, n.6, p.777-784, 2014.

MCCORMACK, M.L.; GAINES, K.P.; PASTORE, M.; EISSENSTAT, D.M. Early season root production in relation to leaf production among six diverse temperate tree species. Plant and Soil, v.389, n. I-2, p. I2I-129, 2015.

MOYER-HENRY, K.; SILVA, I.; MACFALL, J.; JOHANNES, E.; ALLEN, N.; GOLDFARB, B.; RUFTY, T. Accumulation and localization of aluminium in root tips of loblolly pine seedlings and the associated ectomycorrhiza Pisolithus tinctorius. Plant, Cell \& Environment, v.28, n.2, p. I I I-I20, 2005.

MUELLER, K.E.; DIEFENDORF, A.F.; FREEMAN, K.H.; EISSENSTAT, D.M. Appraising the roles of nutrient availability, global change, and functional traits during the angiosperm rise to dominance. Ecology Letters, v. I3, n.5, p.EI-E6, 2010.

PÅHLSSON, A.-M.B. Toxicity of heavy metals ( $\mathrm{Zn}, \mathrm{Cu}, \mathrm{Cd}, \mathrm{Pb}$ ) to vascular plants. Water, Air, and Soil Pollution, v.47, n.3-4, p.287-319, 1989.

PALLARDY, S.G. Physıology of Wood Plants. Academic Press, Elsevier, London, 2008.

PERSSON, H.; AHLSTRÖM, K. Fine-root response to nitrogen supply in nitrogen manipulated Norway spruce catchment areas. Forest Ecology and Management, v. I68, n.I-3, p.29-4I, 2002.

RANGER, J.; GELHAYE, D. Belowground biomass and nutrient content in a 47-year-old Douglas-fir plantation. Annals of forest science, v.58, n.4, p.423-430, $200 \mathrm{I}$.

SEVGI, O.; MAKINECI, E.; KARAOZ, O. The forest floor and mineral soil carbon pools of six different forest tree species. Ekoloji, v.20, n.8I, p.8-I4, 201 I.

SHTANGEEVA, I.; ALBER, D.; BUKALIS, G.; STANIK, B.; ZEPEZAUER, F. Multivariate statistical analysis of nutrients and trace elements in plants and soil from northwestern Russia. Plant and soil, v.322, n. I-2, p.219-228, 2009.

TECIMEN, H.; MAKINECI, E. Aağaçlarda Besin Maddelerinin Yeniden Taşınmasıl Olayıl ve Ekolojik Yönü. Turkish Journal of Forestry, v. I, p.I34-I45, 2007. 
TIAN, S. Effect of precommercial thinning on root development and root and butt decay incidence of red spruce and balsam fir. 2002. p. University of Maine,

TSUNODA, T.; VAN DAM, N.M. Root chemical traits and their roles in belowground biotic interactions. Pedobiologia, v.65, p.58-67, 2017.

TÜFEKÇIOĞLU, A.; KÜÇÜK, M. Soil respiration in young and old oriental spruce stands and in adjacent grasslands in Artvin, Turkey. Turkish Journal of Agriculture and Forestry, v.28, n.6, p.429-434, 2004.

VAN DER PUTTEN, W.H.; BARDGETT, R.D.; BEVER, J.D.; BEZEMER, T.M.; CASPER, B.B.; FUKAMI, T.; KARDOL, P.; KLIRONOMOS, J.N.; KULMATISKI, A.; SCHWEITZER, J.A. Plant-soil feedbacks: the past, the present and future challenges. Journal of Ecology, v. I0I, n.2, p.265-276, 2013.

VOGT, K.A.; PUBLICOVER, D.A.; BLOOMFIELD, J.; PEREZ, J.M.; VOGT, D.J.; SILVER, W.L. Belowground responses as indicators of environmental change. Environmental and Experimental Botany, v.33, n. I, p.189-205, 1993.

WHITE, P., J. Long-distance Transport in the Xylem and Phloem, in: Marschner, P. (Ed.) Marschner's mineral nutrition of higher plants. 2012. p. 49-70.

WILKINS, D. The influence of sheating (ecto-) mycorrhizas of trees on the uptake and toxicity of metals. Agriculture, ecosystems \& environment, v.35, n.2-3, p.245-260, I99I.
WITHINGTON, J.M.; REICH, P.B.; OLEKSYN, J.; EISSENSTAT, D.M. Comparisons of structure and life span in roots and leaves among temperate trees. Ecological monographs, v.76, n.3, p.38I-397, 2006

YANG, L.; WU, S.; ZHANG, L. Fine root biomass dynamics and carbon storage along a successional gradient in Changbai Mountains, China. Forestry, v.83, n.4, p.379-387, 2010.

YIN, X.; PERRY, J.A.; DIXON, R.K. Temporal changes in nutrient concentrations and contents of fine roots in a Quercus forest. Forest ecology and management, v.44, n.2-4, p. I75-184, 1991.

YUAN, Z.; CHEN, H.Y. Fine root biomass, production, turnover rates, and nutrient contents in boreal forest ecosystems in relation to species, climate, fertility, and stand age: literature review and meta-analyses. Critical Reviews in Plant Sciences, v.29, n.4, p.204-221, 2010.

YUAN, Z.; CHEN, H.Y.; REICH, P.B. Global-scale latitudinal patterns of plant fine-root nitrogen and phosphorus. Nature communications, v.2, n. I, p. I-6, 201 I.

ZHAO, N.; YU, G.; HE, N.; WANG, Q.; GUO, D.; ZHANG, X.; WANG, R.; XU, Z.; JIAO, C.; LI, N. Coordinated pattern of multi-element variability in leaves and roots across $C$ hinese forest biomes. Global Ecology and Biogeography, v.25, n.3, p.359-367, 2016. 